\title{
トライボロジーと表面科学
}

\author{
森誠之 \\ 岩手大学工学部 寀 020-8551 岩手県盛岡市上田 4-3-5
}

(2011 年 2 月 14 日受付 ; 2011 年 4 月 6 日掲載決定)

\section{Tribology from the Viewpoint of Surface Science}

\author{
Shigeyuki MORI \\ Faculty of Engineering, Iwate University, 4-3-5 Ueda, Morioka, Iwate 020-8551
}

(Received February 14, 2011 ; Accepted April 6, 2011)

\begin{abstract}
Since tribology is defined as a science and technology of friction and wear between two surfaces with relative motion, tribological phenomena are closely related to surface science. Tribological behaviors are strongly affected by the surface structure of moving contacts, on the other hand, the surface structure is dynamically altering by mechanical contacts, which is very complex and dynamically changing with time. Better understanding of tribological phenomena and development of tribo-systems are deeply dependent on advancement of fundamental research which is supported by a variety of modern surface analytical tools and research techniques in surface science using ultra-high vacuum and advanced surface analytical tools. In tribological phenomena, mechanical energy is supplied to contact surfaces, and so there are many phenomena which are waiting to be studied. Fundamental understanding of tribological phenomena on the bases of surface science provides the development of tribological technologies such as friction, wear and lubrication, and then contribute to develop new tribological technologies for energy saving, eco-friendly lubrication as well as improving the efficiency, safety, reliability and life of machines.
\end{abstract}

KEYWORDS : tribology, boundary lubrication, tribochemistry, surface science, surface analysis

\section{1.はじめに一トライボロジーの役割一}

21 世紀は地球環境と人間活動のバランスを考える時 代である。人間の豊かな生活を支えるために資源やエネ ルギーを利用するが, 地球環境の乱れを最小限にしなけ ればならない。すなわち, エネルギー・資源のインプッ 卜を少なく, 豊かさを増やす技術が求められている。こ れは，効率化の技術であり，トライボロジーはまさに効 率を高める技術である。たとえば，摩擦係数を下げるこ とにより省エネルギーが実現し，また摩耗を減らすこと により材料や部品さらに装置や生産工場の寿命を延ばし 省資源に貢献する（Fig. 1）。耐用年数が 2 倍になれば, 資源も 2 倍有効利用したことになる。その結果として, 燃費が向上し $\mathrm{CO}_{2}$ が削減できる。また，機械・装置・ 工場の寿命が延びることにより，資源の有効利用と技術

E-mail : mori@iwate-u.ac.jp
の信頼性を高めることができる。このように，トライボ ロジー現象の理解と新技術により環境負荷低減を実現す ることができる。トライボロジーは効率化の技術であ り, 人類の活動に伴う様々な力学的運動に付随して起こ る摩擦・摩耗を最適に制御するための潤滑の技術である。

摩擦による熱の発生, 摩耗による材料の損失, これは いずれも接触する界面で, 力学的エネルギーが熱エネル ギーあるいは材料が摩耗粉に散逸する現象である（Fig. 1)。いかに科学技術が進歩しても, 熱力学第二法則に関 わるこれらの散逸過程を無視することはできない。すな わち, トライボロジー現象は人類の活動と密接にかかわ っていることが明らかである。

古代エジプトの壁画に登場するほど潤滑技術の歴史は 古いが, まだ科学技術としての研究課題が多数残されて いる。力学的作用が関わるためトライボロジー現象は複 雑であり，これまで現象の解明が困難であった。一方 で, 生物ことに動物は優れたトライボロジー機構を持っ 


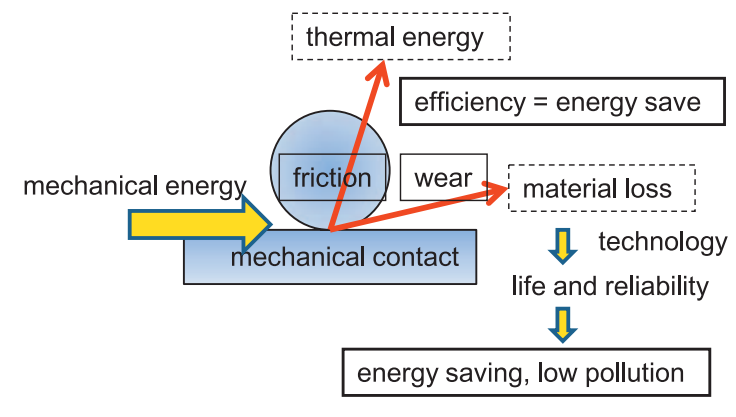

Fig. 1. (color online). Surface phenomena under the effect of mechanical energy.

ている。関節からバクテリア鞭毛モーターの軸受まで, 大変効率の良い潤滑機構を持っている。生物が長い時間 をかけて獲得してきた接触界面の構造が，優れたトライ ボロジー特性を可能にしているのである。言い換えれ ば，光合成や筋肉のように生物が獲得したエネルギー変 換機構と同様に，トライボロジーに扔ても，人類が参 考にすべき摩擦機構や界面構造が多数解明されるのを待 っている。さらに，トライボロジーに関わる基碟的な現 象が解明されれば，新たなトライボロジー技術を生み出 し, 人類活動への恩恵, 地球環境への貝荷低減, さらに 経済的効果は多大であると期待される。ちなみに，トラ イボロジー技術の改善により，GDPの 1-3\%に上る経 済的節滅が可能であるとの試算もある11。トライボロジ 一は古くて新しい表面科学の分野である。トライボロジ 一の歴史については成書 ${ }^{2 \sim 4)}$ を参照頂き，ここでは過去 30 年程度のトライボロジーの進展を表面科学の立場か ら解説する。

\section{2. トライボロジー現象の特徵}

トライボロジー現象に関わる重要なポイントは二つあ り，（1）固体表面あるいは固液界面が接触すること, また（2）接触界面に力学的エネルギーが与えられるこ とである。トライボロジー特性（摩擦，摩耗，寿命な ど）は接触部の表面構造に依存し，一方で表面あるいは 界面の構造は機械的接触によりダイナミックに変化す る。その結果としてトライボロジー特性も変化する。ま た，接触界面に力学的エネルギーが与えられることによ り, 材料は変形, 破壞, 化学結合の切断と反応など, 複 雑な界面現象が起こる。複雑であるため解析が困難であ り, 表面科学の対象となり難かった。昔,「固体は神が 創った。表面は悪魔が作った」とパウリが言ったが，真 空や高純度単結晶を利用し表面構造解析手法の発達によ り, 表面科学は研究の対象として高原の花畑になった。 しかし, トライボロジー現象は表面科学的な解明を待っ
ている状態である。その理由は，力学的エネルギーが接 触界面に作用し, 表面の構造がダイナミックに変化して いるため表面構造の解析を困難にしているからである。

力学的エネルギーが作用する接触部は大変厳しい条件 下にあると言って差し支えない。たとえば，ボールベア リングの接触部では, 温度が $200^{\circ} \mathrm{C}$, 圧力が $1-3 \mathrm{GPa}$ に なる。また，せん断により分子や原子の集団が配向す る。固体であれば結晶の配列が起こり, 潤滑油のような 流体の場合でもせん断により潤滑油分子が配向する。こ のような配向は，「せん断と言う力学場」の中でおこる 特異な現象である。熱的にランダムな動きをする液体で あっても, せん断場の中では分子配向し，その結果とし て物性にも影響する。

トライボロジー特性を評価する重要なパラメーター は, 摩擦係数・摩耗速度・耐荷重能・寿命などである。 これらのマクロなパラメーターは，いずれも接触する固 体界面のミク口な構造に強く依存している。近年の表面 科学的研究手法により, ミクロな接触界面の構造が明ら かにされてきた。摩擦係数は表面の状態により桁違いに 変化する。たとえば，金属の凝着が起こるような厳しい 条件では摩擦係数が 1 を大きく越える。通常の表面は, 酸化物皮膜や有機污染物皮膜が潤滑膜の役目をし, 摩擦 係数は少し低下して 0.1-1 程度，さらに二固体間に潤滑 油が挟まった流体潤滑の場合, 摩擦係数は 0.01-0.1 程度 である。動物の関節表面は高分子やタンパク質の吸着膜 など複雑な構造をしており，その複合構造のお陰で摩擦 係数が 0.001 台まで低下する。このように, 摩擦係数や 摩耗速度は表面の状態に依存して「桁違い」に変化す る。言い換えれば，トライボロジー特性は表面の状態に 敏感であり, 表面あるいは表面膜の構造によりトライボ ロジー特性が制御されることがわかる。

以上のように, トライボロジー現象は表面科学と密接 に関わっており, 以下, 具体的な表面科学の役割と研究 の発展について概観したい。

\section{3. 表面科学との関係}

\section{1 境界潤滑と流体潤滑}

潤滑機構は流体潤滑と境界潤滑に大別され，それぞれ に表面科学が深く関わっている（Fig. 2)。流体潤滑は相 対運動する二つの固体間に潤滑油の流体が満たされ，流 体の粘度特性により潤滑特性が決定づけられる。潤滑油 成分と固体表面との相互作用がトライボロジー特性に影 響するが，これについては後述する。一方，境界潤滑は 二つの固体が接触して運動するため, 上り表面科学との 関係が深い現象である。境界潤滑特性は表面あるいは接 触界面の構造に強く依存する。言い換えれば，境界潤滑 


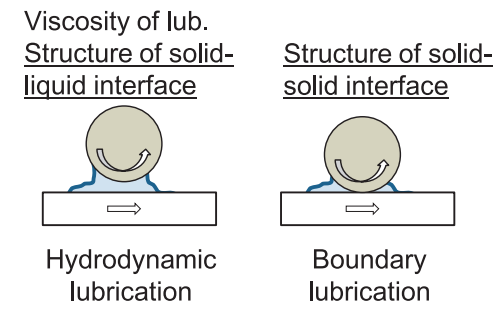

Fig. 2. (color online). Lubrication mechanisms and role of surface structure.

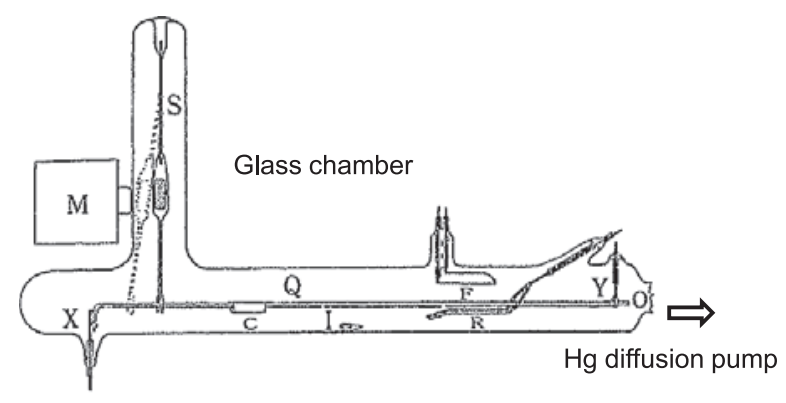

Q: metal wire, C: metal slider, M: magnet, S: spring

Fig. 3. Vacuum apparatus for boundary lubrication tests designed by Bowden.

現象は表面科学的な研究により理解が進んできた。

Fig. 3 は，境界潤滑の父とも呼べる Bowden の実験装 置である5)。Cavendish 研究所の所長であった Bowden は，境界潤滑特性が表面の皮膜により制御されることを 明らかにした。Bowden は，大気中の酸素や金属表面の 污れが摩擦係数に影響すると考え, 真空中で摩擦係数の 測定を行った。1930 年代の研究であるが，これはまさ に表面科学の実験手法である。ガラスの真空容器中に金 属線を張り，その上に置いた金属スライダーの摩擦係数 を測定した。金属線やスライダーに電流を流し，加熱す ることで表面の污れを除去したところ，摩擦係数は 1 を 越える大きな值を示した。ここに少量の酸素を導入する と摩擦係数が激減し, 金属酸化物の皮膜が潤滑効果を示 すことを明らかにした。この研究は, 真空環境を利用し たトライボロジーに関する初めての表面科学的研究であ る。さらに, 脂肪酸の Langmuir-Blodgett 膜が潤滑効果 を示すことを明らかにしている ${ }^{3,4)}$ 。Bowden は摩擦を制 御しているのが表面の構造であることに気づきながら， 構造解析する表面分析手法が当時なかったことを嘆いて いる。

\section{2 摩擦面の構造解析}

境界潤滑現象の理解は, 表面構造解析法の進歩に依存 してきたと言っても過言ではない。摩擦試験が終わった

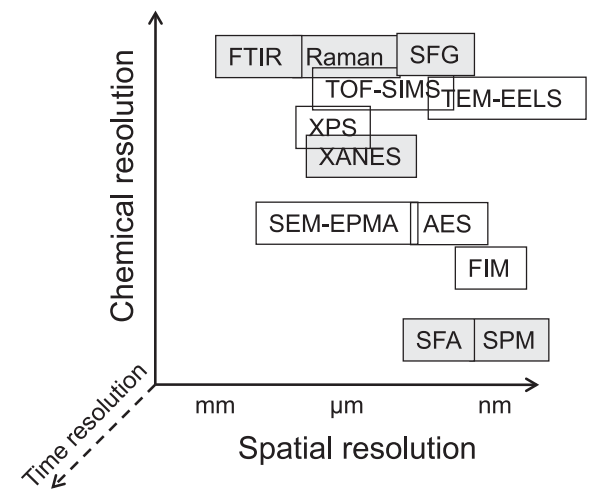

Fig. 4. Surface analytical tools for the investigation of tribology (Tools in a gray box can be used under air).

表面の構造解析に様々な分析法が利用されてきた（Fig. 4)。各種の顕微鏡は, 二次元分解能の向上により原子ス ケールの観察ができるようになった。一方, トライボロ ジー特性は摩擦面の結合構造に敏感であることから, 結 合状態を解析できる分析法の活用により摩擦面の反応と トライボロジー特性の関係が明らかになってきた。今後 は, 摩擦と言うダイナミックなプロセスを明らかにする ために, 時間分解能に優れた分析手法を用いて「その場観 察」を行うことで, 境界潤滑の理解が進むと期待される。 走查型電子顕微鏡 SEM と元素分析 EPMA を組み合わ せた多数の研究により, 材料の観点から摩擦・摩耗の理 解が進んだ。たとえば, SEM による摩擦痕の観察で, 摩耗による表面の破壊状態と力学的な作用との関係が明 らかになった。また，金属材料の摩耗と相手面への移着 現象や，凝着摩耗に対する金属成分の関わりなどが EPMAにより明らかにされてきた。その後, AESや XPS など電子分光法の進歩により化学構造の解析が可 能になり, 潤滑特性に関わる表面の構造が明らかになっ てきた。NASAの Buckley は境界潤滑現象の解明のため にいち早く AES を研究に取り入れ, 表面科学の手法を 応用して摩擦の根源を探る研究で成果をあげたの)。すな わち，高純度金属の表面を超高真空中でエッチングによ り清浄にした。表面が化学的に清浄であることは AES により確認し, 超高真空中で摩擦試験をした結果, 摩擦 倸数は界面に扔ける化学結合に依存することを示した (Fig. 5)。すなわち，遷移金属の清浄面を用いて各種の セラミックススライダーと摩擦したところ, 遷移金属の 摩擦係数は遷移金属のパーセント d 特性に依存して右下 がりの傾向が得られた。化学的に活性が高い金属ほど高 い摩擦係数を示し, 接触界面における化学的な相互作用 が摩擦の本質であることを示している。

XPS は表面の化学構造を知るのに適している。潤滑 で表面に生成する化合物を知ることにより，摩擦面にお 


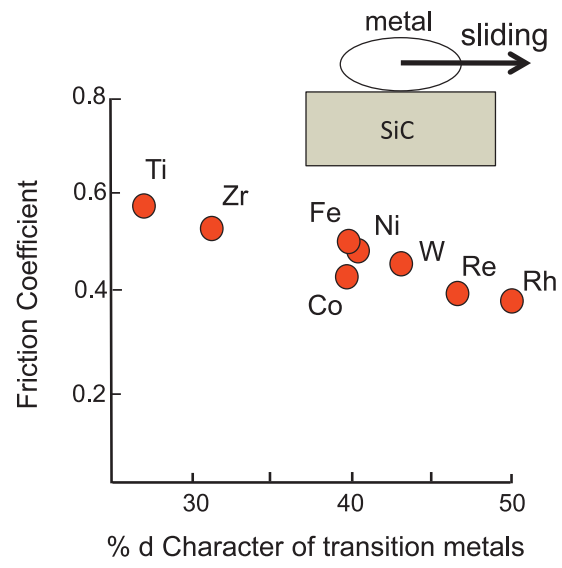

Fig. 5. (color online). Relationship between chemical activity of transition metals and friction coefficient with $\mathrm{SiC}$ slider.

ける反応機構や境界潤滑機構が明らかになってきた。た とえば，潤滑油には性能を向上させるためにリンや硫黄 を含む添加剤が加えられており, 摩擦面で反応しリン酸 エステル吸着物，ポリリン酸，リン酸塩》や金属の硫化 物, 硫酸塩 ${ }^{8}$ などが生成し, 耐摩耗性や耐荷重能の向上 に関わることが明らかにされてきた。一方，真空中で金 属清浄面を準備し微量の酸素により金属酸化膜を作り, XPS で測定した酸素の被覆率が 1 に近いほど摩擦係数 が低下した99。すなわち，金属酸化物膜は単分子層程度 あれば摩擦係数を下げるのに役立つことが示された。

近年進歩が著しいTOF-SIMS を用いた研究により， 接触界面におけるより詳細な情報が得られるようになっ た。たとえば，ハードディスク表面の潤滑油薄膜（厚さ $1 \mathrm{~nm})$ が摩擦により分解する過程が解析された。すな わち，フッ素系の潤滑油が低荷重でも分解すること，卜 ライボ化学反応によりサファイアがフッ化アルミニウム を作り容易に摩耗することなどが報告されている ${ }^{10)}$ 。試 料の化合物に ${ }^{2} \mathrm{H}(\mathrm{D}),{ }^{13} \mathrm{C}$ あるいは ${ }^{18} \mathrm{O}$ を導入することに より，摩擦面に扔ける化合物の分布を TOF-SIMS で追 跡するいわゆるトレーサーとしての利用が可能である ${ }^{11}$ 。

\section{3 その場観察}

Fig. 4 に示した表面分析装置のうち電子およびイオン をプローブとする方法は, 真空を必要とするため, 潤滑 油と大気の存在下では表面分析ができない。そのため, 潤滑試験が終わった試験片のオイルを洗浄により除去す るなど，分析の前処理に工夫がなされてきた。一方，卜 ライボロジー現象の特徵は, ダイナミックに運動してい るときの界面構造にある。このため, 潤滑状態のその場 観察が行われるようになってきた ${ }^{12)}$ 。先にも述べたよう に, トライボロジー現象はダイナミックな現象であり,
言わば「生きた現象」をそのまま捉える「その場観察」 が, 現象の解明とトライボロジー現象の理解に必要であ る。大気中でのその場観察には, 電磁波を用いた分光法 が有効である。電磁波はエネルギーにより，ラジオ波赤外線-可視・紫外線- $X$ 線一 $\gamma$ 線などがある。それぞれ の電磁波の吸収スペクトルょり, 様々な構造に関する情 報が得られる。表面構造解析にも様々な分光法が利用さ れているが，トライボロジーでは顕微赤外分光法を利用 して潤滑状態にある潤滑油膜のその場観察が行われてい る。最近では, 和周波数分光法 SFG が界面構造に敏感 な分析法として注目され，コンタクトレンズの水潤滑に 関わる表面分析が行われている ${ }^{13)}$ 。

\section{4. 流体潤滑における界面構造}

流体潤滑では，二つの固体表面に挟まれた流体（潤滑 油）の粘度特性が支配的因子である。ボールベアリング のように球が接触する場合, 応力が集中し接触部の圧力 は $1 \mathrm{GPa}$ (約 1 万気圧）以上になる。したがって，トラ イボロジー特性は潤滑油の高圧物性とくに高圧粘度に依 存し，これは潤滑油の分子構造に関係している。弾性流 体潤滑の場合, 設計に使えるモデルが既にでき上がって おり，これは言わばバルクの問題である。しかし，近年 流体潤滑における界面の問題がクローズアップされてい る ${ }^{14)}$ 。流体潤滑で，接触界面に潤滑油が流入するために は，材料に対する潤滑油の濡れ性が重要な因子になる。 潤滑油がせん断を受けることにより摩擦抵抗が発生する が，クエット流れのモデルでは材料の表面で閏滑油分子 は停止している。しかし, 潤滑油分子と材料表面との相 互作用が弱ければ「界面滑り」が起こり, 摩擦特性に影 響する。たとえば，平滑な雲母の表面をアルキルシラン で疎水性処理をした試験片と未処理の試験片を用いて, 水ーグリコール混合物を潤滑油として摩擦係数を測定し た。親水性の未処理雲母に比べ, 表面処理をした雲母を 用いると低摩擦係数が得られた ${ }^{15)}$ 。これは, 固-液界面 の親和性がトライボロジー特性に関与している例であ り，今後一層検討が望まれる。

潤滑油は混合物であり，様々な添加剤が加えられてい る。添加剤は固体表面と相互作用をして吸着膜や様々な 表面構造を形成し, トライボロジー特性に影響を与えて いる。安定な吸着膜により摩擦係数が低下する。一般 に, アルキル鎖が長い脂肪酸の吸着膜は摩擦係数を低下 させる ${ }^{16)}$ 。吸着膜を高分子にすることにより，優れた弾 性流体潤滑特性が得られている ${ }^{17)}$ 。ポリアクリル酸メチ ル PMA に吸着性の側鎖をつけることにより，潤滑性の 吸着膜が形成し, 低速でも低摩擦係数を示すことが報告 されている。吸着性の官能基は分子末端に置くことによ 
り効果が発揮され, 界面の吸着構造が潤滑性に関与して いる証拠である。グリースは繊維状ミセルのネットワー クが油分を保持する半固体状の潤滑剤である。このネッ トワークが表面を被覆することによりトライボロジー特 性が向上することが知られている。また, 潤滑油にアミ ド化合物を加えたゲル状潤滑郕はアミドによる柔らかい ネットワーク構造が作られ，これが材料表面を被覆して 潤滑特性が向上することがわかってきた ${ }^{18)}$ 。このよう に, 流体潤滑でも固一液界面に形成されるネットワーク 構造がトライボロジー特性に関与しており, 界面構造に ついてさらに検討が必要である。

\section{5. トライボロジー現象の特異性}

トライボロジー現象は, 接触界面に力学的作用が加わ るため, 潤滑中の物質は特異な条件にさらされる。たと えば，先に述べたように弾性流体潤滑条件では，接触部 で高温・高圧が発生する。さらに, 潤滑油にせん断が加 えられるとせん断場に打いて分子が配向する。

せん断による分子配向は粘度の非ニュートン性に関わ る。液晶のように平面構造を持つと, せん断面に平行に 分子が配向し, 摩擦係数低下に寄与する ${ }^{19}$ 。

弾性流体潤滑条件ではヘルツ接触部で高圧が発生す る。そのサイズは厚さ $1 \mu \mathrm{m}$ 以下, 直径は荷重に依存す るが $200 \mu \mathrm{m}$ 程度である。接触部では容易に高圧が発生 し, いわばマイクロリアクターとしてヘルッ接触部を利 用することができる。一方, 低速・高荷重の条件では油 膜が形成されず, 固体の直接接触が起こり, 様々な構造 変化が観察される。一般に固体表面は, 安定な構造にな っている。たとえば金属の場合, 金属酸化物や有機污染 物質で被覆され, 表面は化学的に保護されている。しか し, 固体接触により表面の保護膜が除去されると, 化学 的に活性な表面が露出する。力学的作用により作られる 表面は格子欠陥に富み, 化学活性は一層高くなると予想 される。一方，セラミックスのように共有結合性の高い 結合を持つ固体では, 力学的作用により固体が摩耗し, 切断した結合はラジカルサイトとして作用する。さら に,グラインダーで金属を研磨する時に経験するよう に, 摩擦面では光やプラズマが発生し, その物理化学的 作用に興味が持たれている。このような摩擦面で起こる 反応をトライボ化学反応と呼んで扔り, この反応により 境界潤滑膜が形成されることから, 摩擦表面の化学現象 の解析も重要な表面科学的課題である ${ }^{20)}$ 。水の電気分解 による水素生成（電気エネルギー）あるいは光合成によ る二酸化炭素と水から糖の生成（光エネルギー）のよう

に, 力学的エネルギーが接触界面に関与することによ り, トライボ化学反応が誘起される。境界潤滑現象を理
解するためには, トライボ化学現象を正しく知らねばな らない。

\section{6. マイクロ・ナノトライボロジー ${ }^{21)}$}

原子間力顕微鏡 (AFM) や表面力測定装置 (SFA) など, ナノスケールの測定技術が進歩し, ナノスケール のトライボロジーすなわちナノトライボロジーの研究が 盛んになってきた。一方, スケールが縮小されることに より, トライボロジー現象は表面構造に強く依存するよ うになる。具体的には, 表面力 $F_{\mathrm{s}}$ と物体を動かすとき の慣性力 $F_{\mathrm{i}}$ の比は式のようにサイズの二乗 $L^{2}$ に逆比例 して大きくなる。ここで, $\gamma$ は表面張力, $\alpha$ は加速度, $\rho$ は密度およびVは体積である。式（1）からわかるよう に, 小さな物体が接触する時の摩擦係数は, 荷重よりも 表面張力 $\gamma$ すなわち表面の構造に強く依存することがわ かる。

$$
\frac{F_{\mathrm{s}}}{F_{\mathrm{i}}}=\frac{\gamma L}{\alpha \rho V}=\frac{\gamma L}{\alpha \rho L^{3}}=\frac{\gamma}{\alpha \rho L^{2}}
$$

AFM を用いた研究により, 摩擦の本質が明らかにな ってきた。グラファイトの摩擦測定により, 原子間隔で

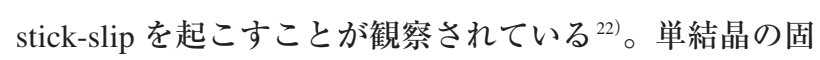
体表面だけでなく Langmuir-Blodgett LB 膜など単分子膜 や配向構造とトライボロジー特性が検討されている。興 味深いのは, $\mathrm{CF}$ 結合を持つ単分子膜のナノトライボロ ジー特性である。PTFE のように CF 結合を持つ高分子 は表面エネルギーが低く, 低摩擦係数が得られると理解 されている。しかし，アルキル鎖に CF 結合を持つ単分 子膜を試料として AFM で摩擦力を計測すると, $\mathrm{CH}$ の アルキル鎖よりも高い值が得られた ${ }^{23}$ 。これは, パーフ ルオロアルキル鎖は回転の運動に障害があるためと説明 されている。一方, 相対する表面構造のマッチングから 極低摩擦が起こることが予言され, 雲母を用いた研究に よりそのような結果が得られている24)。

SFA を用いた研究により, 平滑な雲母の平面に挟ま れた分子状薄膜のトライボロジー特性が検討され, バル クとは異なる興味深い結果が得られている。たとえば, シクロヘキサンは小さく丸い分子でありバルクの粘度は 低いが, 数分子から単分子膜のシクロヘキサンの摩擦係 数は 1 より大きくなった。また, その単分子膜では固体 接触特有のスティックースリップ現象が観察され, シク ロヘキサンの融点以上であっても固体のように振舞うこ とが示された ${ }^{25)}$ 。同様に, 丸い分子であるオクタメチル シクロテトラシロキサン OMCTS の分子状薄膜も高い摩 擦係数を示した。これらの分子は表面と相互作用し, 丸 いため固体のような配列構造をとりやすく, 固体接触し たときのトライボロジー特性（stick-slip）を示したと考 
えられている（Fig. 6)。これに対して，ポリブテンのよ うに側鎖を持つ高分子流体は粘度が高く，バルクの摩擦 係数は高くなる。しかし, 分子状薄膜になると空孔が多 いためせん断により滑らかに移動し, 摩擦係数も 0.03 と低い值を示した。これらの結果は, 分子状薄膜のせん 断特性がバルクのそれとは異なることを示しており,こ れも表面の影響によるものである。先に述べたシクロへ キサンの分子状薄膜が粘度上昇することは, EHLの実 験結果からも得られており ${ }^{26)}$, 流体分子と表面との相互 作用により界面構造が作られ，これがトライボロジー特 性に強く関わることが明らかになってきた。

ナノトライボロジーを実用化しているのが，ハードデ

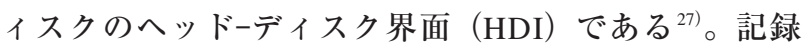
密度を向上させるために, ヘッドとディスクの間隙（ス ペーシング）が狭まって扔り, 現在数 $\mathrm{nm}$ にまでなって いる。このため, ヘッドがディスクに衝突することがあ り, 磁性層の保護のために $3 \mathrm{~nm}$ 程度のダイヤモンドラ イクカーボン DLC がコーティングされている。さらに 潤滑特性を向上させるために, フッ素系の特殊潤滑油 (perfluoropolyether oil : PFPE) が $1 \mathrm{~nm}$ 塗布されている (Fig. 7)。潤滑油分子は主鎖がパーフルオロエーテルで あり表面張力が低い。分子の末端にはアルコール性水酸 基があり, DLC 表面に吸着してディスクの高速回転に よる遠心力で潤滑油が失われるのを防いでいる。一方,

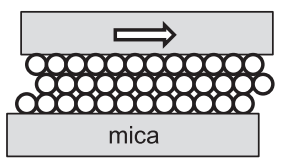

spherical molecule $=$ low viscosity alignment at interface $\mu=$ more than 1 stick-slip

Fig. 6. Nanotribological behavior and structure of molecularly thin films.

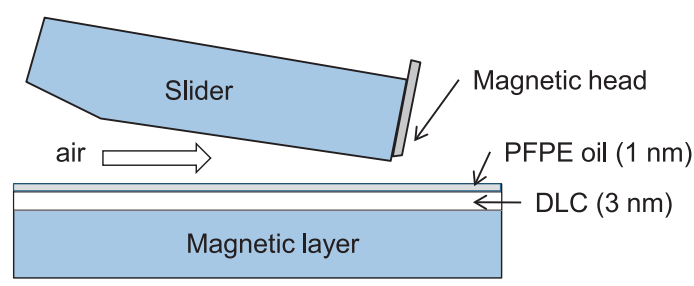

Fig. 7. (color online). Nanotribology at head-disk interface of magnetic hard disk.
表面に固定していない潤滑油分子は，損傷を受けた部分 に拡散し補修する役割を持っている。また，摩擦により フッ素系潤滑油が分解し，HDI の寿命に影響を与える。 極低荷重の摩擦においても，フッ素系潤滑油が分解し低 分子量の気体が発生する。反応過程を TOF-SIMS で追 跡した研究では, 分解は接触するスライダー材料の触媒 作用により促進されることが明らかにされている。さら に，サファイアスライダーであっても，極低荷重でフッ 素系潤滑油と反応し, $\mathrm{AlF}_{3}$ を生成して摩耗（化学摩耗） することが報告されている ${ }^{10)}$ 。フッ素油は表面張力が小 さいため摩擦低減の他, HDI に水が㠜縮して付着する のを防止する効果もある。今後，マイクロマシンやナノ マシンなどの害用に際しては, 改質した表面の構造と卜 ライボロジー特性の関係がますます重要になると予想さ れる。

\section{7. 生体のトライボロジーと水潤滑}

生体とくに動物には動く部分がたくさんある。関節や まぶたなどはわかりやすい。筋肉もアクチンとミオシン の滑りにより収縮する。鞭毛モーターの軸受はナノサイ ズである。人工関節に扔ける課題は，低摩擦係数の実現 と耐久性であり, 後者は耐摩耗性の向上が求められ る ${ }^{28)}$ 。関節の潤滑性は界面の構造に依存しており, これ は関節表面の構造と関節液の組成により最適な構造が作 られている。また，生体の潤滑は水を媒体として行われ ており, 粘度が低い水でも潤滑できる界面構造の構築が 重要である。生体の潤滑機構は研究の途上であり, 次第 に明らかにされつつある。

一方, 技術的にも水潤滑は魅力がある。水は不燃性, 冷却性, 無毒さらに安価であることから, 水による潤滑 が可能になれば，人類にも地球にも優しい潤滑技術と言 える。水の弱点は, 粘度が低く, 接触部に液膜を作りに くいことである。そこで様々な界面科学的な工夫がされ ている。一つは, 水と油の混合物すなわちエマルション を作り, 水媒体で水の特徵を生かし, 油で潤滑するもの である。鋼板の圧延では，エマルション潤滑が行われて いる。水で泠却し, エマルションから分離した油が接触 界面に介在して潤滑している。この場合, エマルション の粒径, 界面活性剤の種類と濃度, 鋼板と油の濡れ性な ど, 界面科学的な操作パラメーターにより潤滑性能が制 御されている ${ }^{29)}$ 。また, 霧状の水滴の表面に油膜を形成 し，エマルションと同様に水の泠却力と油の潤滑性を利 用することも可能である。さらに，グリコールのように 水に溶解した有機成分が加熱による相変化で析出し, 潤 滑性能を得ることも行われている。

以上述べてきたのは，技術として利用されている水が 
関与する潤滑であるが，いずれも油を利用している。動 物の関節を真似るのは難しいが，水潤滑を実現する界面 構造を構築するための研究が行われている。ハイドロゲ ルは潤滑に用いる水を大量に保持できることから，八イ ドロゲルを用いた水潤滑の研究が行われている。最もポ ピュラーなのは, ポリビニルアルコールである。八イド ロゲルの親水性を疎水性官能基に変えることにより, 潤 滑性能が低下する。力学的に強度の高いハイドロゲルも 実現しており，水潤滑への応用が期待されている。ま た, 関節液に含まれるたんぱく質, ヒアルロン酸を複合 することにより低摩擦や耐久性の向上に寄与している。 界面構造を積極的に構築する研究も進んでいる。ポリ $\mathrm{L}$ リシンをバックボーンにして, 水と親和性の高いグリコ 一ルの側鎖を持ち, 残ったアミノ基で固体表面に吸着 し, 潤滑膜を形成する。グリコール鎖が水を確保して, 水潤滑が可能になり, 極低速でも低摩擦係数が得られて いる ${ }^{30)}$ 。の分子の場合, バックボーンの長さ, 吸着サ イトの数，側鎖の数と長さを分子設計することができ, これらの構造に依存した潤滑特性がえられることが示さ れた。親水性ナノダイヤモンドが水潤滑に利用されてい る ${ }^{31}$ 。一般にダイヤモンドの表面は疎水性であるが, 特 殊な製法で得られたナノダイヤモンドは親水性で水に良 く分散する。このコロイド液を接触界面に介在させるこ とにより, 摩擦係数が低下した。この場合, 蒸発損によ る水だけを供給することにより, 潤滑性が維持できてい る。 $\mathrm{pH}$ を制御することにより, 界面の電気二重層の反 発により荷重を支え, 低摩擦を得ることができる ${ }^{32}$ 。 $\mathrm{AFM}$ を用いてシリコン基板（表面は $\mathrm{SiO}_{2}$ ) と $\mathrm{Si}_{3} \mathrm{~N}_{4}$ の 針との摩擦力を水中で測定した。それぞれの等電点は 2.8 および 6.5 であり, $\mathrm{Si}_{3} \mathrm{~N}_{4}$ の等電点以上では, 双方の 表面が負に帯電するため反発力により荷重を支えること ができる（Fig. 8)。したがって，等電点以上の $\mathrm{pH}$ で摩 擦力が低下している。一方, 表面張力を利用した潤滑機 構が考えられている。Laplaceの式より, 液内外の圧力 差 $\Delta P$ は液体の表面張力 $\gamma$ に比例し, 二面間に挟まれた 液体が作るメニスカスの半径 $r$ に逆比例して大きくな る。

$$
\Delta P=\frac{4 \gamma}{r}
$$

濡れる液体では内圧が低くなり, 両面は張り付く。この ため, マイクロマシンなどの隙間に水が凝縮すると水の 付着力により摩擦力が異常に大きくなることから, マイ クロマシンの表面は疎水性にしておかねばならない。一 方, 濡れない液体の場合は内圧が高くなるため, 荷重を 支えることができる（Fig.9）。この支える力は，挟まれ た液体の表面張力に比例し, メニスカスの半径に逆比例

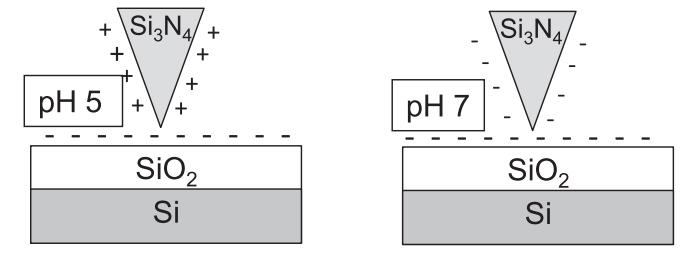

Fig. 8. Friction control in water by $\mathrm{pH}$.

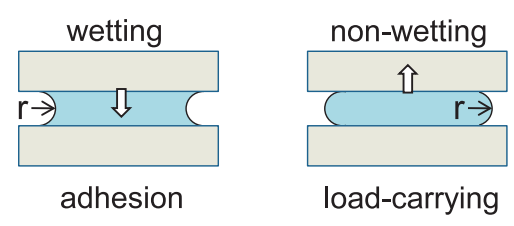

Fig. 9. (color online). Adhesion of wetting liquid and loadcarrying by non-wetting liquid.

する。したがって，大きな表面張力を持つ液体を狭い隙 間に挟むことにより液膜により荷重を支えることができ る ${ }^{33)}$ 。たとえば，水銀 $(\gamma=485 \mathrm{mN} / \mathrm{m})$ を $20 \mu \mathrm{m}$ の隙間 $\left(\mathrm{r}=10^{-5} \mu \mathrm{m}\right)$ に挟み, 液膜が $10 \mathrm{~cm} \times 10 \mathrm{~cm}\left(0.01 \mathrm{~m}^{2}\right)$ の場合, $2000 \mathrm{~N}$ （約 $200 \mathrm{kgf}$ ）の荷重を支えることがで きる。水銀よりもガリウムは表面張力が大きいので, 融 点以上であればガリウムが利用できる。また, 安全な液 体として水があるが, 疎水性の表面を準備することによ り水で荷重を支えることができる。この方法で重要なこ とは，二つの表面間に安定な液の薄膜を作ることであ り，これには平滑な表面を準備しなければならない。

\section{8. 今 後 の 課 題}

\section{1 新しい素材}

優れた潤滑性能を得るために新しい素材がトライボロ ジー材料あるいは潤滑材料として提案されている。摩擦 接触の力学的作用から表面を保護するために, 様々な硬 質材料あるいは硬質薄膜が検討されてきた。先に述べた 境界潤滑の立場からは, 下地材料が硬いことは低摩擦を 得るためにも有効である ${ }^{34}$ 。金属の炭化や窒化, 各種セ ラミックスのコーティングなどが検討されてきた ${ }^{35)}$ 。最 も研究され塞用に供されているのはダイヤモンドライク カーボン DLC である ${ }^{36)}$ このほかに, C-B-N の三元系 からなる, 硬質材料のトライボロジー特性が研究されて いる ${ }^{37) 。}$

DLC は，比較的硬質で平滑な表面が得られることか ら, そのトライボロジー特性の研究が進み, 実用化も多 くなされている。硬質を利用して様々な潤滑部品の耐摩 耗皮膜として害用されている。特に, 加工工具の表面処 理として多用されている。また, 適当な環境では低摩擦 
を得るのにも効果がある。たとえば，自動車エンジンで は，最も厳しい潤滑条件であるバルブリフターとカムの 接触部がある。バルブリフターの表面に DLC を被覆し, C，H，O だけからなる添加剤と組み合わせることによ り低摩擦を得ている ${ }^{38)}$ 。また，先にも述べたように，八 ードディスクの磁気記録層の表面を被覆し，ヘッドによ る機械的な損傷および $1 \mathrm{~nm}$ の潤滑膜の分解を防いでい る (Fig. 7)。

\section{2 新しい潤滑油}

摩擦・摩耗を低減することは，エネルギー消費を減ら し機械の寿命を延ばすことから，潤滑油は環境負荷の低 減に直接役立っている。一方, 潤滑剂の素材に環境負荷 の低い原料を利用することが求められている。現在, 潤 滑油の基油は鉱油が多く, 添加剤には $\mathrm{P}, \mathrm{S}$ あるいは $\mathrm{Zn}, \mathrm{Mo}$ などの金属を含む化合物が用いられている。こ れは，材料表面にリン酸化合物やイオウ化合物の潤滑膜 を形成する。また，亜鉛の塩が耐摩耗性に寄与し，さら に $\mathrm{MoS}_{2}$ は摩擦係数を下げるために効果を発揮し，これ らの特性は表面科学の課題である。これら従来の潤滑油 成分に変わる環境負荷が少ない化合物, たとえば C, $\mathrm{H}, \mathrm{O}$ だけからなる化合物や，重金属を含まない化合物 の探索が続けられているが, 摩擦面での作用機構の解明 が待たれる ${ }^{39}$ 。 イオン液体は, 蒸気圧が低いため蒸発損 がないこと，また反応性が低く劣化が少ないことなどの 特徵を持つことから, 特殊環境下に扔ける潤滑油として 注目されている。摩擦接触する表面ではイオン液体も容 易に反応することが知られている。最もポピュラーなア ニオンである TFSA の場合 $\mathrm{CF}_{3}$ を持つことから，金属 と反応し金属フッ化物を生成する。このため, 金属フッ 化物が低摩擦係数に寄与するが，一方，化学摩耗を促進 する原因でもある ${ }^{40)}$ 。

\section{3 超潤滑}

摩擦係数が 0.01 未満になる潤滑を超低摩擦 Super low friction coefficient あるいは超潤滑 Super lubricity と呼ん でいる ${ }^{41)}$ 。様々な界面構造により, 超潤滑が可能である ことが報告されている。二硫化モリブデンは層状構造を しており，グラファイトと同様に固体潤滑剤として知ら れている。二硫化モリブデンが酸化した酸化モリブデン は潤滑性がそしい。そこで, 超高真空中で二硫化モリブ デンの皮膜を調製し，そのまま真空中で摩擦係数を測定 したところ超潤滑が観察された ${ }^{42}$ 。これは, 摩擦界面で 高配向した二硫化モリブデンによることを TEM の観察 により明らかにしている。その他にも，DLC を真空中

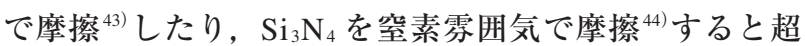
低摩擦係数が得られている。これらの結果は接触する界 面の構造に関わると考えられている。また， $\mathrm{C}_{60}$ を用い
た超潤滑も報告されている ${ }^{45)}$ 。

一方，水環境での超潤滑が報告されている。たとえ ば，ダイヤモンドを水中で摩擦すると超潤滑が得られ る ${ }^{46)}$ 。また, $\mathrm{Si}_{3} \mathrm{~N}_{4}$ 同士を水中で摩擦しても超潤滑状態 が得られる。これは，摩擦により接触界面に生成するゲ ル状物質による潤滑効果と考えられている47)。また，水 潤滑の項でも述べたように，親水性のポリグリコール鎖 を持つ化合物の吸着膜により，水による流体潤滑により 超潤滑が得られることが報告されている。いずれの超潤 滑現象も摩擦面に生成する構造に基づくものであり，今 後その構造解析と機構の解明に興味が持たれる。

8.4 コンピュータシミュレーション

分子動力学法を用いたコンピュータシミュレーション によるトライボロジーの研究が進み, 固体接触やせん断 による接触界面の様子が可視化できるようになってき た。また，分子スケールのシミュレーションは，AFM やSFA による観察結果と対比することにより相互の理 解が進んできた。たとえば，Landman は金属の接触と せん断による原子スケールのダイナミックな動きを紹介 した ${ }^{48}$ 。分子シミュレーションと有限要素法を組み合わ せることにより，ナノとミクロをつなぐトライボロジー の理解が進んでいる ${ }^{49)}$ 。さらに, 分子動力学法を潤滑油 分子に適用することにより，せん断場にある分子の配向 やせん断抵抗などを解析することができるようになっ た ${ }^{50)}$ 。

\section{9.おわりに}

トライボロジーの表面科学は, 未解明の課題がたくさ ん残されている新天地である。トライボロジー現象には 力学的エネルギーが関与するため, 接触界面の構造がダ イナミックに変化している。未解明のトライボロジーの 表面科学をさらに追及するためには，トライボロジー現 象のその場観察が必要であり, そのためには新しい表面 分析手法と摩擦試験法を組み合わせた新しい研究システ ムの構築が待たれる。一方, トライボロジー現象に関与 するエネルギーで整理すると, はじめに力学的エネルギ 一が接触界面に与えられ，これが界面で熱，光，および 電気エネルギーに変換される。したがって，それらのエ ネルギーが関与してトライボロジー現象が起こるため, 接触界面で起こる現象が複雑になる。接触界面では, 物 理的な構造変化にとどまらず，いわゆるトライボ化学反 応が起こり, 表面の構造がダイナミックに変化してい る。これらの構造変化に関わる外的因子として，（1） 接触条件（摩擦速度, 荷重（接触面圧）など)，（2）接 触材料 (力学的特性, 表面状態など), (3) 潤滑剂成分 （基油, 添加剤など）および（4）環境成分（雲囲気, 
湿度など）があげられる。これらの組み合わせは無限に あることから，実際の潤滑における現象を解析するので はなく, 本質に迫る基本的な現象について表面科学の手 法により解析して行くことが望まれる。トライボロジー の表面科学には, 常識が打ち破られる現象が多数残され ている。これは, まさしく発見の糸口であり, 技術革新 への近道である。

トライボロジーの語源はギリシャ語の tribos + logy で あり，イギリスで生まれた。その基礎的研究はヨーロッ パに始まり，アメリカに移って成長し，いまや日本をは じめとするアジアに拠点が移りつつある。これまでのト ライボロジーに関する研究は, 機械工学, 材料工学ある いは応用化学などの視点から進められてきており, 境界 領域の研究分野である。これまで述べてきたように, ト ライボロジーは本質的に表面科学の一部であることか ら，より基碟的に理解を媣めるために表面科学的なアプ ローチが望まれる。

\section{文献}

1)市川雪則, 四阿佳昭: トライボロジスト 46, 907 (2001).

2) D. ダウソン : “トライボロジーの歴史”, 「トライボロ ジーの歴史」編集委員会訳 (工業調查会, 1997).

3) F.P. Bowden and D. Tabor : "The Friction and Lubrication of Solids" (Clarendon Press, Oxford, 1950).

4) バウデン, テイバー : “固体の摩擦と潤滑”曽田規範 宗訳 (丸善, 1976).

5) F.P. Bowden and T.P. Hughes : Proc. Roy. Scc. A172, 263 (1939).

6) D.H. Buckley: "Surface Effects in Adhesion, Friction, Wear, and Lubrication", Tribology Series, 5 (Elsevier, Amsterdam, 1981).

7) M. Gauvin, F. Dassenoy, C. Minfray, J.M. Martin G. Montagnac and B. Reynard: J. Appl. Phys. 101, 1 (2007).

8) M. Eglin, A. Rossi and N.D. Spencer : Tribology Letters 15, 199 (2003).

9) B.M. DeKoven and P.L. Hagans : J. Vac. Sci. Technol. A8, 2393 (1990).

10) T. Numata, H. Nanao, S. Mori and S. Miyake : Tribology International 36, 305 (2003), ハードディスク.

11) T. Kubo, H. Nanao, S. Mori, Y. Enomoto, N. Nie and H. Nomura : Wear 268, 1225 (2010).

12) H.A. Spikes : Tribology Letters 14, 1 (2003).

13) S.J. Kweskin, K. Komvopoulos and G.A. Somorjai : Langmuir 21, 3647 (2005).

14) 森 誠之:トライボロジスト 56, 18 (2011).

15) J.H. Choo, H.A. Spikes, M. Tatoi, R. Grovnea and A. Forrest : Tribology International 40, 154 (2007).

16) 日本トライボロジー学会編: “トライボロジーハンド ブック” (養賢堂, 2001) p. 598.

17) J. Fan, M. Mueller, T. Stoher and H.A. Spikes : Tribology
Letters 28, 287 (2007).

18) 設楽裕治：トライボロジスト 56, 37 (2011).

19) S. Mori and H. Iwata: Tribology International 29, 35 (1996).

20) 森 誠之: JTEKT Eng. J. No. 1008, 2 (2010).

21) N. Ohmae, J.M. Martin and S. Mori: "Micro and Nanotribology" (ASME Press, New York, 2005).

22) S. Morita, S. Fujisawa and Y. Sugawara : Surf. Sci. Rep. 23, 12 (1996).

23) R.M. Overney, E. Meyer, J. Frommer, D. Brodbeck, R. Luti, L. Howald, H.J. Guntherrod, M. Fujihira, H. Takano and Y. Gotoh : Nature 359, 133 (1992).

24) 平野元久:トライボロジスト 51, 849 (2006).

25) J.N. Israerachivili, P. McGuiggan, M.G.A. Homola, M. Robbins and P. Thompson: J. Phus., Condens. Matter 2, SA89 (1990).

26) G.J. Johnston, R. Wayte and H.A. Spikes : Tribology Trans. 34, 187 (1991).

27) 金子礼三: “ゼロ摩耗への挑戦 マイクロトライボロ ジーの世界” (オーム社, 1995).

28) 村上輝夫 : トライボロジスト 51, 707 (2006).

29) 下斗米直, 森誠之: トライボロジスト 56, 47 (2011).

30) M. Mueller, S. Lee, H.A. Spikes and N.D. Spencer : Tribology Letters 15, 395 (2003).

31) 森 誠之, 菅野 葵, 七尾英孝, 大澤映二: 機能材料 29, 30 (2009).

32) A. Marti, G. Harner and N.D. Spencer : Langmuir 11, 4632 (1995).

33) J. Chappius : Wear 77, 303 (1982).

34) 榎本祐嗣, 三宅正二郎: “薄膜トライボロジー” (東京 大学出版, 1994) p. 44.

35) 大原久則 : トライボロジスト 55, 563 (2010).

36) 野老山貴行, 梅原徳次 : 同上 54, 22 (2009).

37) 三宅正二郎 : トライボロジスト 44, 414 (1999).

38) J. Ye, K. Ueoka, M. Kano and Y. Yasuda : Tribology Series 43, 693 (2003).

39）山下幸人: トライボロジスト 53, 443 (2008).

40) 森 誠之: 表面技術 60,34 (2009).

41) 平野元久:トライボロジスト 51, 849 (2006).

42) J.M. Martin, C. Donnet and T. Le Mogne: Phys. Rev. B48, 10583 (1993).

43) C. Donnet, A. Grill, J. Fontaine, T. Le Monge and L. Lefebvre : Lubrication at the frontier 36, 333 (1999).

44) 足立幸志: トライボロジスト 51, 861 (2006).

45) 三浦浩治, 佐々木成朗: トライボロジスト 51, 879 (2006).

46) Y. Tseng : Appl. Phys. Lett. 63, 3586 (1993).

47) M. Cheng, K. Kato and K. Adachi : Tribology Letters 11, 23 (2001).

48) U. Landman, W.D. Luedtke, N.A. Burnham and R.J. Colton : Science 248, 454 (1990).

49) 井上 滉, 佐々木直哉, 井上陽一, 小山昌喜: トライ ボロジスト 44, 403 (1999).

50) 田村宏之, 宮本 明: トライボロジスト 45, 655 (2000). 